\title{
Konstruksi Identitas Kedaerahan oleh Media Massa Lokal
}

\author{
Putri Aiysiyah Rachma Dewi \\ Program Studi Ilmu Komunikasi, \\ Universitas Muhammadiyah Malang
}

\begin{abstract}
This article focuses on how the local print media view of regional identity artists involved in the video contained sexual scenes. The author raised the case of video sexual scenes involving Ariel, Luna Maya, and Cut Tari. All three are national artist when the video was circulated in the society. The three newspapers under study are the Bali Post, Serambi Indonesia, and Pikiran Rakyat. The results showed that the three newspapers was to discredit the three artists with the construction of such news. The newspaper did not give chance for artists to express their opinions.
\end{abstract}

Keywords : identity, media, cultural construction

\section{Latar Belakang}

Makalah ini berfokus pada bagaimana media cetak lokal melihat identitas kedaerahan artis yang terlibat dalam video berisi adegan seksual. Penulis mengangkat kasus video adegan seksual yang melibatkan Ariel, Luna Maya, dan Cut Tari. Ketiganya adalah artis nasional yang namanya tengah melambung ketika video tersebut beredar di masyarakat. Ariel, sebagai vokalis band Peterpan yang menjadi pemenang Dahsyat Award, Panasonic Gobel Award (PGA), dan Anugerah Musik Indonesia. Luna Maya, presenter acara musik terpopuler versi PGA, "Dahsyat RCTI". Sedangkan Cut Tari, pembawa acara "Insert" acara infotainment peraih rating tertinggi menurut AC Nielsen.

Hal yang menarik adalah bahwa ketiga selebritis, meski telah menjadi artis nasional dan menetap di Jakarta, yang menjadi ibukota negara Indonesia, akan tetapi masing-masing dari mereka masih membawa identitas kedaerahan masingmasing. Tak dapat dipungkiri bahwa pada masing-masing artis tersebut masih melekat identitas lokal yang berbeda, seperti gelar "Cut" yang disandang Cut Tari, Ariel yang identik dengan Bandung, dan Luna Maya yang besar dalam kultur Bali dan sangat bangga dengan identitas ke-Bali-an yang ia miliki.

Ketiganya menjadi sosok yang dianggap mampu membawa nama daerah masing-masing ke kancah nasional. Media lokal pun sebelum kasus ini mencuat, mengelu-elukan mereka sebagai sosok putra daerah yang berhasil. Kini, pasca kasus video adegan seksual yang melibatkan mereka bertiga, bagaimana media melihat identitas lokal atau kedaerahan yang dimiliki para artis tersebut. Misalkan sebuah berita yang dimuat di harian Serambi Indonesia tanggal 10 Juni 2010, sesaat setelah video 
tersebut beredar. Mereka menyatakan kritik akan nilai-nilai lokal yang dibawa Cut Tari karena nama "Cut" yang ia sandang adalah identitas Aceh yang merujuk pada nilai-nilai religiusitas seseorang.

...seorang Cut Tari, wanita dan ibu keturunan Aceh terlebih dengan gelar Cut yang sudah berbadabad dijaga kehormatannya oleh masyarakat Aceh, harusnya bisa menjadi contoh yang baik bagi masyarakat Indonesia. (Serambi Indonesia, 10 Juni 2010)

Kutipan di atas merupakan pernyataan dari Sekretaris Umum Ikatan Mahasiswa dan Pemuda Aceh (IMAPA) Jakarta, Alfi Syahriati ketika diwawancarai oleh harian Serambi Indonesia berkait keterlibatan Cut Tari dalam video berisi adegan seksual yang mirip dirinya dengan vokalis grup band Peterpan, Ariel.

Alfi Syahriati sebagai orang Aceh merasa sangat risih dengan nama "Cut" yang disandang oleh Cut Tari, selebritis papan atas Indonesia. Baginya nama Cut memiliki keistimewaan dan menuntut serangkaian tanggung jawab penyandangnya. Bagi Warga Aceh, Cut adalah gelar bagi para perempuan bangsawan keturunan Sultan Aceh "Uleebalang", dan yang laki-laki bergelar “Teuku” di depan nama mereka.

Tulisan ini bermaksud untuk melihat bagaimana identitas kedaerahan individu dikonstruksi oleh media massa melalui pemberitaan-pemberitaan yang mereka muat. Ada tiga media massa lokal yang menjadi obyek pengamatan penulis, yaitu Pikiran Rakyat (Bandung), Serambi Indonesia (Aceh), dan Bali Post (Bali). Pemilihan tiga media dengan asumsi bahwa masing-masing menjadi mainstream media di daerahnya. Unit yang diamati adalah kata-kata yang ada di dalam setiap berita yang berkaitan dengan kasus video porno ketiga selebritis. Untuk pengumpulan data, penulis mengambil versi online agar tiada satupun berita yang terlewati sejak kasus ini muncul yaitu 3 Juni 2010 hingga 30 Juni 2010.

\section{Kisah Video Porno Artis}

Video porno yang dimaksud mulai diunggah di internet pada 3 Juni 2010. Video pertama yang beredar adalah video Ariel dan Luna Maya ${ }^{1}$. Rekaman berdurasi sekitar tiga menit tersebut berisi adegan seksual antara Ariel dan Luna Maya. Rekaman diambil melalui kamera handphone. Sementara, berselang tiga hari kemudian, muncul video kedua yang menampilkan Ariel dan Cut Tari sedang berhubungan seks. Secara cepat video tersebut menyebar. Kecanggihan teknologi internet menjadi katalisator terdistribusinya video kepada khalayak luas. Selama dua pekan, layanan internet mengalami lonjakan traffic yang signifikan, ditambah dengan layanan semakin membludaknya pengguna layanan telepon pintar seperti blackberry yang memungkinkan seseorang mengunduh video dimanapun dan kapanpun ia inginkan. ${ }^{2}$

Berita seputar skandal video ini pun juga menjadi perbincangan internasional, Harian Amerika Serikat, The New York Times dan juga CNN turut membicarakan dan mewawancarai Ariel. Di situs majalah Time.com, berita Ariel masuk di posisi keempat berita terpopuler. Peristiwa ini hanya dikalahkan oleh

\footnotetext{
Penulis memilih tidak menggunakan kata "mirip" Ariel-Luna Maya, agar tidak menimbulkan paradoks dengan berbagai perkembangan temuan-temuan yang mereduksi kata "mirip" itu sendiri.

2 www.Tempointeraktif.com Selasa, 08 Juni 2010
} 
tiga peristiwa lain : fenomena kokain di kalangan kelas menengah, pencemaran oli oleh British Petroleum dan Cina yang akan mempenetrasi pasar Afrika.

Di Indonesia, video yang paling banyak diunduh adalah video porno tiga bintang ini. Dalam waktu tiga hari setelah diunggah pertamakali, jumlah pengunduh mencapai lebih dari tiga ratus ribu orang atau rata-rata seratus ribu orang perharinya ${ }^{3}$. Belum lagi apabila para pengunduh ini kemudian menyebarkan kepada rekan-rekannya. Dapat dibayangkan betapa isu video ini segera menjadi isu publik yang diperbincangkan hampir seluruh lapisan masyarakat. Di ruang kuliah, warung kopi, di kantor-kantor, di sekolah mulai SD-SMA, arisan PKK, hingga pengajian ibu-ibu di kampung punikut meramaikan perbicangan seputar video tersebut.

Media massa memiliki andil besar dalam hingar bingar skandal ini. Hampir seluruh media massa yang ada di Indonesia tak luput dari pemberitaan mengenai kasus video porno Ariel, Luna Maya, dan Cut Tari. Bahkan majalah Tempo, yang selama ini mem-positioningkan diri sebagai media "serius" dan relatif bebas dari berita khas infotainment, ternyata ikut latah memberitakan kasus nge-pop ini.

Tentu tidak semua media memiliki suara seragam dalam melihat persoalan yang ada, masing-masing memiliki sudut pandang yang berbeda berdasar referensi jurnalis pada fakta yang ada dan ideologi institusi media. Faktorfaktor ini berpengaruh pada wacana yang mereka sajikan. Hal ini tercermin pada bahasa-bahasa yang mereka gunakan. Apa yang tersaji pada produk berita

Berita "Skandal Seks Artis" tanggal 10 Juni 2010, wwW.liputan6.com mereka mengindikasikan nilai-nilai tertentu, yang disadari ataupun tidak merupakan upaya penjejalan isme-isme tertentu kepada pembacanya. Seperti yang dikemukakan oleh Foucault, bahwa wacana tidaklah pernah netral atau berdiri sendiri. Bahasa adalah sebuah wacana yang berkait dengan aturan, hakhak istimewa untuk kelompok tertentu yang diberikan oleh pemegang kuasa. Lewat teori-teori yang dikemukakannya, Foucault menyadarkan dunia bahwa bahasa sebagai alat melanggengkan kekuasaan kelompok tertentu. "Language as a discourse is never neutral and is always laden with rules, privileging a particular group while excluding other".

Berikut pengamatan penulis terhadap ketiga media lokal yang ada (Pikiran Rakyat, Serambi Indonesia, dan Bali Post) terhadap pemberitaan seputar video porno artis Indonesia. Untuk Pikiran Rakyat terdapat 10 item berita, Bali Post 8 item berita, dan Serambi Indonesia sebanyak 6 item berita. Kesemua berita tersebut diunggah dalam kurun waktu tanggal 3-30 Juni 2010.

\section{Analisis}

Bali Post: Video Seksual, Pelanggaran Nyata terhadap Nilai Moralitas Masyarakat

Salah satu aspek penting dalam pemberitaan adalah rubrikasi, yaitu bagaimana sebuah peristiwa (dan berita) dikategorisasikan dalam rubrik-rubrik tertentu. Sebuah peristiwa tentu dapat dilihat dari berbagai sudut pandang, apakah sebagai fenomena sosial, persoalan ekonomi, masalah hukum atau kriminal, peristiwa nasional atau lokal, human interest, atau hanya hiburan semata.

\footnotetext{
Yasraf A. Piliang; Resistensi Gaya Hidup; 2006; Jalasutra: Jogjakarta
} 
Rubrikasi peristiwa berhubungan dengan bagaimana realitas dipahami dan dimengerti atau apa yang seharusnya ditekankan oleh khalayak dalam melihat suatu peristiwa atau realitas. ${ }^{5}$ Dalam kasus video adegan seks selebritis ini, ada berbagai sisi peristiwa yang melingkupinya. Beberapa di antaranya: adalah sisi hukum karena termasuk pada ranah pornografi dan pornoaksi; sisi sosial karena dampak yang ditimbulkan terhadap masyarakat; sisi hiburan karena menyangkut pelaku industri entertainment Indonesia, dan juga sisi politik karena adanya beberapa kecurigaan bahwa isu video porno hanyalah isu semu untuk menutupi persoalan-persoalan lain yang lebih urgent dari hadapan publik yang berkait dengan penyelenggaraan negara (keberlanjutan kasus Century, Dana Aspirasi Parlemen, Rekening Misterius Jenderal Polri, dan lain sebagainya).

Dari ketiga media, Bali Post ternyata memiliki kecenderungan yang berbeda dalam mengklasifikasikan berita video porno ini. Bali Post cenderung melihatnya sebagai peristiwa hukum sehingga seluruh berita yang diturunkan selalu melihat pada ranah proses hukum yang ada. Mulai dari pasal-pasal yang dapat dikenakan pada ketiga artis yang terlibat hingga setiap perkembangan penyelidikan yang dilakukan oleh pihak kepolisian.

Bali Post berusaha untuk mengemas berita ini "secerdas mungkin" dengan menempatkannya pada kategori "Peristiwa dan Hukum". Dapat diartikan bahwa Bali Post berusaha melihatnya sebagai insiden pelanggaran terhadap norma hukum yang berlaku. Bali Post

\footnotetext{
Edelman dalam Eriyanto, Analisis Framing: Konstruksi, Ideologi, dan Politik Media; 2007 (hal. 164)
}

menggunakan kepolisian dan aparat hukum lain sebagai sumber utama berita-berita mereka. Mulai dari Kapolri, Kabareskrim, Kadiv Humas Polri, Kepala Pusat Kedokteran dan Kesehatan Polri, Kabid Penerangan Umum, dan Wakadiv Humas Polri tercatat pernah setidaknya satu kali dikutip komentarnya dalam pemberitaan. Dan, seluruh komentar yang dimuat berisi keterangan pasalpasal yang dapat dikenakan kepada ketiga pelaku yang ada di rekaman video.

...bila terbukti ketiga figur terkenal terancam terkena pasal berlapis karena secara sadar mendokumentasikan. (Wakadiv. Humas Polri)....Kabareskrim, Ito Sumardi menyatakan pemeriksaan terhadap Ariel-Luna Maya menanyakan proses pembuatan video dan kenapa gambar itu bsia beredar. ("Ariel-Luna Gandengan Tangan Diperiksa Polisi di Mabes Polri, BP/12-06 2010)

Selain kepolisian, narasumber lain yang tercatat adalah Ketua Komisi Perlindungan Anak Indonesia, Hadi Supeno. Meski dirinya diwawancarai sebagai ketua KPAI, yang seyogyanya bicara mengenai dampak video terhadap anak-anak, namun justru Bali Post mengutip pendapat dalam konteks hukum yaitu pasal-pasal yang dapat dikenakan kepada ketiga artis yang terlibat.

...pelaku yang diduga Ariel, Luna Maya, dan Cut Tari dapat dijerat dengan tiga undang-undang. Mereka tidak dapat mengelak dari Undang-undang Nomor 44 Tahun 2008 tentang pornografi; Undang-undang No. 11 tahun 2008 pasal 27 ayat 1 tentang Informasi dan Transaksi Elektronik; dan, Pasal 282 Kitab Undang-undang Hukum Pidana tentang Tindakan Asusila... (Dipanggil Polisi Ariel-Luna Maya Sakit, Cut Tari diantar Suami, BP/15-06-2010) 
Bali Post mencoba mengkonstruksi peristiwa ini sebagai sebuah pelanggaran terhadap norma hukum yang ada. Terlepas dari kontroversi antara hak individu untuk membuat dokumentasi versus undang-undang pornografi dan pornoaksi yang tidak memberi celah sedikitpun kepada pembuatan video dengan content seksual baik untuk pribadi maupun disebarkan kepada masyarakat. Sehingga apapun alasannya, ketiga artis tersebut melakukan suatu hal yang salah. Labelling terhadap produk video tersebut juga mencerminkan hal ini. Bali Post beberapa kali menyebutnya sebagai "video mesum" dan "adegan film asusila". Konteks mesum merupakan peyorasi akan hubungan seksual antar manusia. Asusila menunjukkan bahwa Bali Post memandang apa yang dilakukan oleh ketiga artis adalah hal-hal yang tidak sesuai dengan norma kesusilaan yang berlaku di masyarakat.

Bali Post seolah menafikkan bahwa seksualitas adalah bagian tak terpisahkan dari kehidupan. Bahwa kehidupan itu bermula dari hubungan seksual antara laki-laki dan perempuan. Seringkalimedia massa turut mengkonstruksi pemikiran bahwa seks merupakan sesuatu yang tabu, aib yang harus ditutupi. Sehingga setiap pelanggaran terhadap tabu tersebut layak mendapatkan hukuman bagi pelakunya. Hukuman tersebut juga diberikan oleh Bali Post dengan cara tak memberikan ruang terhadap "para pendosa" untuk bersuara. Tak ada satupun komentar dari ketiga pelaku yang dimuat. ${ }^{6}$

6 Tentu alasan yang digunakan oleh media massa bahwa narasumber tidak mau memberikan komentar. Akan tetapi, penulis melihat bahwa tehnik doorstep (mencegat narasumber untuk mendapatkan pernyataan) adalah cara instan dan tidak efektif untuk mendapatkan keterangan. Ironisnya, justru jalan ini yang seringkali diambil oleh para jurnalis, sehingga jawaban "no comment" dari narasumber yang
Memang, penasihat hukum mereka beberapa kali dimintai keterangan dan dimuat dalam berita Bali Post, namun kutipan berita komentar yang ditampilkan justru menyudutkan si artis itu sendiri, alih-alih menyuarakan kepentingan mereka. Misalkan, pernyataan O.C Kaligis, pengacara Ariel-Luna Maya, bahwa Ariel sebagai korban dalam kasus ini dan semua harus diserahkan kepada penyelidikan pihak kepolisian. Pernyataan Ariel dan Luna Maya sebagai korban mengindikasikan bahwa mereka bukan sedang menuntut namanya dicemarkan, tetapi mereka adalah dua orang tak beruntung yang rekaman videonya disebarluaskan oleh pihak-pihak yang tidak bertanggung jawab.

Ketidakberpihakan Bali Post juga tampak pada berita yang berjudul, "Tatto di pinggul Luna Dihilangkan? Ariel Belum Akui Terlibat Adegan Porno" (BP/ 19-062010). Berita ini adalah berita yang paling jelas menunjukkan logika berpikir yang digunakan Bali Post. Dari judul berita, kata "belum" dipilih untuk menunjukkan bahwa suatu ketika (apabila saatnya telah tiba) maka akan muncul pengakuan dari Ariel dan rekan-rekannya bahwa benar merekalah pelaku dalam video tersebut, bukan orang lain yang mirip secara fsik dengan mereka. Kutipan narasumber lagi-lagi mengkuatkan logika berpikir yang demikian bahwa si pelanggar norma ini seharusnya segera dijatuhi hukuman yang setimpal dan mengalami hidup sebagai rakyat jelata di dalam bilik penjara.

Seperti mitos Adam dan Hawa yang terusir dari surga karena pelanggaran yang mereka lakukan, dan mereka hidup

berjalan tergesa-gesa sudah cukup mengakhiri usaha mereka mencari keterangan. 
sengsara di dunia.

...Ariel, Luna Maya dan Cut Tari belum mengakui terlibat adegan porno pada video yang beredar di masyarakat. Demikian diungkapkan Direktur I Keamanan Transnasional Badan Reserse Kriminal Mabes Polri Brigadir Jenderal Pol. Saud Usman Nasution, Jumat (18/6) kemarin. Meski demikian, Saud menegaskan, penyidik tidak membutuhkan pengakuan dari ketiga selebriti yang masih berstatus saksi korban itu, karena polisi bekerja berdasarkan pembuktian untuk menjadi alat bukti. "Kita tidak perlu pengakuan, tetapi alat bukti yang cukup untuk membuat konstruksi hukum," kata Saud.(Tato di Pinggul LM dihilangkan ?, BP/ 19-06-2010)

Selain kepolisian, narasumber lain yang tercatat adalah Ketua Komisi Perlindungan Anak Indonesia, Hadi Supeno. Meski dirinya diwawancarai sebagai ketua KPAI, yang seyogyanya bicara mengenai dampak video terhadap anak-anak, namun justru Bali Post mengutip pendapat dalam konteks hukum yaitu pasal-pasal yang dapat dikenakan kepada ketiga artis yang terlibat Undang-undang Nomor 44 Tahun 2008 tentang pornografi; Undang-undang No. 11 tahun 2008 pasal 27 ayat 1 tentang Informasi dan Transaksi Elektronik; dan pasal 282 Kitab Undang-undang Hukum Pidana tentang Tindakan Asusila).

Hal lain yang menarik adalah pernyataan menteri Komunikasi dan Informasi, Tifatul Sembiring. Meski mengakui bahwa lembaga yang ia pimpin masih bekerjasama dengan kepolisian untuk mengungkap siapa pelaku video Akan tetapi di lain pernyataan yang dikutip, ia menyatakan jika beredarnya video porno tersebut telah menganggu banyak pihak, termasuk dirinya dalam menjalankan tugas negara.
Ariel, Luna, dan Cut Taripun menjadi pesakitan dalam lembar-lembar Bali Post. Melalui pemilihan kata, kategorisasi, dan juga penyusunan alur cerita, secara sadar ataupun tidak Bali Post telah mengajak pada pembaca untuk mempercayai keaib-an hubungan seksual, dan siapapun yang ketahuan melakukan hubungan seksual maka ia layak mendapatkan hukuman. Tak perlu proses hukum yang panjang untuk mencari siapa yang salah, karena pelaku adalah satu-satunya pihak yang bersalah dalam kasus ini. Pelaku di sini merujuk kepada ketiga artis papan atas Indonesia.

\section{Serambi Indonesia: Gelar "Cut" Tak Layak Disandang oleh Pelaku Video Porno}

Apabila Bali Post melihat peristiwa video porno ini sebagai persoalan hukum, maka pendekatan yang berbeda dilakukan oleh harian lokal Aceh, Serambi Indonesia. Koran dengan oplah terbanyak di Aceh ini memandang realitas ArielLuna-Cut Tari sebagai permasalahan sosial. Dengan demikian sudut pandang yang digunakan oleh mereka dalam mengemas berita video artis ini tentu dari sudut pandang dampak sosial yang ditimbulkannya. Beberapa tema yang muncul selalu berkait dengan efek lanjut dari kehadiran sang artis dalam video porno. Budaya Aceh yang kental dengan nuansa Islami merasa terusik dengan zina yang dilakukan oleh idola mereka. Beberapa judul berita yang mereka gunakan menunjukkan hal tersebut, misalkan: "Warga Aceh Kecewa Jika Benar Cut Tari Beradegan Mesum" (10/06); "Ariel Dilaporkan ke Polisi dan Dewan Pers" (13/06); "Cut Tari Cs dicekal Masuk Aceh" $(18 / 06)$.

Bagi Serambi Indonesia, aktor utamanya bukanlah Ariel melainkan Cut 
Tari. Ini yang membedakan pemberitaan mereka dengan media massa lain. Media massa lain menempatkan Ariel sebagi lakon utama dalam cerita video porno ini. Nama Cut yang identik dengan Aceh menjadikan Cut Tari sebagai fokus utama perhatian mereka. Cut dalam budaya Aceh merujuk pada gelar bagi para perempuan bangsawan keturunan Sultan Aceh "Uleebalang”, dan yang lakilaki bergelar "Teuku" di depan nama mereka. Bangsawan Aceh dituntut untuk mampu menjadi panutan dan pengayom bagi rakyat kebanyakan sehingga mereka memiliki ekspektasi moralitas tinggi kepada individu yang bergelar Cut atau Teuku.

Kebanggan Aceh terhadap sosok Cut Nyak Dien, pahlawan perempuan yang dikenal karena ketegarannya dan semangat perjuangannya melawan kolonialisme di bumi Serambi Mekah. Beliau menjadi panglima perang, setelah suaminya Teuku Umar gugur dalam peperangan. Seorang perempuan dengan baju dan rambut yang disanggul khas Aceh dengan pedang yang diselipkan di antara selendang inilah yang dijadikan mitos akan keanggunan seorang "Cut".

Sementara, Cut Tari yang hadir dengan rambut terawat yang indah dibiarkan tergerai. Baju yang dikenakannya hampir selalu minimalis dan memperlihatkan seluruh pesona tubuhnya yang indah kala di depan kamera sangat mengusik warga Aceh. Kemarahan semakin memuncak terhadap Cut Tari ketika ia terseret pada kasus video porno. Serambi Indonesia, juga berperan serta dalam menyuarakan kemarahan-kemarahan warga. Beritaberita yang disajikan merepresentasikan kekecewaan. Meskipun dengan kedok yang hampir sama yaitu menggunakan mulut ketiga (narasumber) untuk melegitimasi subyektifitas pemberitaan mereka. Berikut beberapa contoh kutipan yang ada dalam berita SI:

..."sebagai public figure, semestinya mereka menjadi panutan. Bukan justru sebaliknya" Pernyataan Wakil Gubernur Aceh, M. Nazar.

...Ulama Aceh, Tengku H. Nuruzzahri mendukung langkah pemerintah Aceh mencekal artis yang terlibat video porno masuk ke Aceh.

...Aceh harus disterilkan dan jangan diberi keleluasaan orang luar masuk Aceh yang tidak selaras dengan syariat. Kebijakan Wagub yang melanggar syariat tidak boleh masuk Aceh suatu kemaslahatan untuk penegakan syariat Islam.

...Cekal dan boikot hasil karya tiga artis yang diduga terlibat video mesum adalah suatu hal yang baik dan patut didukung. (Anggota Komisi G DPRD Aceh, Tgk. Mohariandi)(dalam "Cut Tari cs Dicekal Masuk Aceh", SI/ 18-062010)

Untuk labelling terhadap beberapa hal juga menunjukkan bahwa Serambi Indonesia memandang video porno sebagi pelanggaran terhadap syariat Islam yang menjadi landasan konstitusi di daerah Aceh. Serambi Indonesia lebih senang menggunakan istilah "video mesum" daripada "video porno', juga ada istilah "film mesum" yang mengandung kecurigaan adanya unsur sengaja dalam produksi maupun distribusinya, "kasus asusila", "adegan mesum", "video syur", "adegan asusila", "Perbuatan tidak senonoh" menguatkan indikasi bahwa apa yang dilakukan oleh ketiga artis tak pantas, tak layak, tak patut, dan suatu hal yang memalukan. Sehingga pelakunya haruslah diberi hukuman seberat-beratnya, dan identitas "Cut" yang disandang Cut Tari Aminah Anasya 
(nama asli Cut Tari) harus dicabut.

\section{Pikiran Rakyat: Bandung Tak Lagi Bangga Memiliki Ariel}

...mereka semua tidak boleh tampil di kota Bandung. Grup band Peterpan boleh tampil asal tanpa Ariel. (Walikota Bandung, Daz Rosada) (Ariel Terancam Tercoret Sebagai Warga Kota Bandung, PR/ 14-06-2010)

Kutipan di atas merupakan salah satu isi berita seputar video porno Ariel Peterpan di harian Pikiran Rakyat. Sepintas sepertinya apa yang disuarakan oleh walikota mewakili suara mayoritas warga Bandung namun ternyata tak semua sepakat dengan ide mendepak Ariel dari Bandung.

Nazriel Ilham, sebelum peristiwa video porno mencuat adalah salah satu anak daerah yang menjadi kebanggan kota Bandung. Sukses besar yang diraih Peterpan diakui tak lepas dari tangan dingin Ariel yang menciptakan sebagian besar lagu-lagu yang dibawakan grup band terpopuler ini. ${ }^{7}$ Dapat dipastikan apabila Peterpan tampil di Kota Kembang, sambutan yang didapatkan pun selalu hangat dan meriah.

Pasca beredarnya video, ternyata gambaran Ariel sebagai pemuda Bandung yang sukses dalam merintis karir musiknya menjadi kandas. Kekecewaan publik tercermin dari banyaknya hujatan yang dilayangkan kepada Ariel diunggah di situs Pikiran Rakyat, meski tak dapat dipungkiri sebagian masyarakat juga melihat kasus ini bukanlah kesalahan Ariel semata. Ariel, Luna Maya, dan Cut Tari hanyalah korban dari moralitas yang bobrok di masyarakat.

Sementara itu Pikiran Rakyat sebagai

Menurut Indonesia Music Award 2009 institusi sosial ia juga memiliki nilainilainya sendiri dalam melihat persoalan Ariel. Pada awal kasus, Pikiran Rakyat masih menggunakan label "rekaman video dengan adegan seksual". Label tersebut terkesan lebih netral dan based on fact karena faktanya di dalam rekaman yang diberitakan memang berisi adegan seksual antara Ariel dan Luna Maya maupun Ariel dengan Cut Tari. Penggunaan istilah "mesum" atau "asusila" muncul di kemudian hari seiring dengan ditemukannya bukti-bukti yang mengarah pada bahwa memang benar adanya jika di video tersebut adalah sosok Ariel yang sebenarnya. Jadi bukan seseorang hanya kebetulan mirip Ariel.

Meski demikian, Pikiran Rakyat berbeda dengan dua media lain yang secara tegas menghakimi ketiga figur artis. Pikiran Rakyat berusaha melihat dari berbagai sudut pandang yang berbeda, sehingga berita yang muncul ada yang masuk pada kategorisasi hukum dan kriminal, kategori hiburan, atau kategori peristiwa sosial. Dari sisi pemilihan narasumber, Pikiran Rakyat juga berusaha mencakup semua pihak yang mewakili bermacam kepentingan (mulai dari Polri, kuasa hukum artis, narapidana lain, awam, dan juga pemerintah). Hal ini dapat dimengerti, karena Bandung adalah salah satu kota di Indonesia dengan toleransi terhadap nilai-nilai baru sangat tinggi.

Bisa jadi apa yang dilakukan oleh Pikiran Rakyat ini adalah imbas dari dimungkinkanya komunikasi interaktif antara media dengan pembacanya yaitu melalui cara online. Berdasar pengamatan data diketahui bahwa sebagian komentarkomentar yang masuk juga menganggap media massa terlalu lebay atau membesarbesarkan peristiwa ini dalam berita mereka. 


\section{Media, Identitas, dan Konstruksi Budaya}

Realitas sosial bagi kaum konstruktivis adalah produk dari manusia, hasil proses budaya, termasuk didalamnya penggunaan bahasa. Van Dijk menyatakan bahawa lewat kampanye (dis)informasi kelompok kuat dapat menanamkan ideologi mereka kepada kelompok lemah. ${ }^{8}$ Seperti yang diungkap oleh Mc. Quail, media massa memiliki kemampuan unutk menyaring sebagian pengalaman dan menyoroti pengalaman lainnya dan sekaligus kendala yang menghalangi kebenaran. ${ }^{9}$

Makna suatu peristiwa, seperti halnya video porno Ariel, Luna Maya, dan Cut Tari yang diproduksi dan disebarluaskan oleh media massa, sebenarnya merupakan suatu konstruksi makna yang temporer dan subyektif. Apa yang dituliskan menjadi berita tentu bukanlah mewakili realitas yang sebenarnya. Proses selektifitas, mulai dari selektif terhadap peristiwa hingga selektifitas makna, yang dilakukan oleh jurnalis dan editor, disadari atau tidak berperan dalam menghasilkan judul berita, pemilihan katagori, pemilihan labelling; pemilihan narasumber dan kutipan narasumber, pemilihan foto, dan lain sebagainya.

Banyak informasi dalam sebuah wacana (berita) itu tidak nampak secara eksplisit, namun lebih secara implisit. Kata, kategorisasi, klausa, metaformetafor, bisa jadi mengisyaratkan konsep atau proposisi-proposisi yang dapat diduga berdasarkan frame of references dan field of experiences. Tentu apabila kita berbicara tentang dua hal tersebut (frame

8 Eriyanto, Analisis Wacana Kritis, 2006 (hal. 13)

9 Stephen W. Littlejohn, Theories of Human Communications, 1996 (hal. 324) dan field) tak dapat kita lepaskan dari konteks budaya yang melingkupinya. Dengan kata lain, media menjadi agen dalam transformasi dan internalisasi nilai-nilai budaya. Termasuk di dalamnya adalah identitas seseorang berdasar daerah tempat ia dibesarkan.

Identitas tak dapat dipisahkan dari budaya, karena ia tidak dimiliki oleh individu-individu, akan tetapi dimiliki secara kolektif dalam suatu kelompok. MenurutRutherford, identitas merupakan satu mata rantai masa lalu dengan hubungan-hubungan sosial, kultural, dan ekonomi di dalam ruang dan waktu satu masyarakat hidup. ${ }^{10}$ Dengan kata lain, identitas sebagai sebuah objek komunal berfungsi sebagai pembeda antara satu anggota masyarakat budaya atau daerah tertentu dengan budaya atau daerah lain. Identitas ini juga yang digunakan sebagai takaran insiders atau outsiders. Orang Jawa, orang Aceh, Melayu, Sunda, Arek Surabaya, dan lain sebagainya adalah contoh identitas, karena penyebutan individu sebagai "orang Jawa" atau "orang Aceh" membawa konsekuensi tertentu tentang bagaimana individu tersebut membangun konsep diri dan mengidentifikasi dirinya pada suatu kelompok masyarakat tertentu.

Akan tetapi karena sifatnya yang komunal, maka individu tak memiliki kuasa atas identitas yang dilekatkan kepadanya. Orang-orang seperti Ariel, Luna, dan Cut Tari tak memiliki sebuah daya untuk melawan apa yang dibentukkan bagi mereka. Kepasrahan mereka untuk dicerabut identitas kulturalnya (Ariel dicoret jadi warga Bandung, Luna dihakimi oleh media Bali, dan Cut Tari yang dianggap tak

10 Yasraf A. Piliang; Dunia yang Dilipat; 1998 (Hal. 159) 
layak menyandang gelar "Cut") kembali harus tunduk kepada media sama seperti ketidakberdayaan mereka ketika identitas-identitas tersebut dijejalkan secara paksa pada diri mereka.

\section{Daftar Pustaka}

Eriyanto (2007). Analisis Framing: Konstruksi, Ideologi, dan Politik Media. Yogyakarta, Lkis

Eriyanto (2006). Analisis Wacana Kritis. Yogyakarta, Lkis
Littlejohn, Stephen W.\&Karen Foss (2008). Theories of Human Communications. Belmont, Thompson Wadsworth

McQuail, Dennis \& Sven Windahl (1993). Communication Models. London, Longman

Piliang, Yasraf A. (1998). Dunia yang Dilipat. Bandung, Mizan

Piliang, Yasraf A. (2006). Resistensi Gaya Hidup. Yogyakarta, Jalasutra

www. tempointeraktif.com diunduh pada 08 Juli 2010

www.liputan6.com diunduh pada 10 Juni 2010 